\title{
THE TRIUMPHANT GENEALOGICAL AWARENESS OF THE NOBILITY IN THE GRAND DUCHY OF LITHUANIA IN THE 17TH AND 18TH CENTURIES
}

\author{
Agnè Railaité-Bardè \\ (Lithuanian Institute of History)
}

\begin{abstract}
This article attempts to show how the manifestation of ancestors was expressed in the genealogical awareness of the nobility in the Grand Duchy of Lithuania, using publications to mark special occasions in the 17th and 18th centuries, genealogical trees and diagrams. The research seeks to establish what effect the exaltation of various battles had on the genealogical memory of the nobility in the Grand Duchy, bearing in mind the context of its involvement in one of the most famous battles it ever fought. The genealogical sources mentioned were examined in order to ascertain which battles and what memories of the commanders who fought in them were important to the genealogical awareness of the nobility, and why this memory was selective, for some battles and notable heroes from these battles are remembered and glorified, while others are simply forgotten. Memories of which battles were important to the genealogical presentation of certain families, how was it expressed, and in what period were the ancestors who participated in these battles remembered?

The first part of the study presents the memory of ancestors as soldiers, and the ways this memory was expressed. The second part focuses on ancestors who distinguished themselves in specific battles, and which family members who participated in battles are remembered and honoured, in this way distinguishing them from other ancestors.
\end{abstract}

KEYWORDS: Grand Duchy of Lithuania; nobility; genealogical awareness; militaristic; heraldry.

War was an important part of society in the Grand Duchy of Lithuania (GDL), for it was one of the most important engines of the state mechanism. Its significance has been recorded in Lithuanian chronicles. In terms of their legendary aspect, genealogy is like the warp of a fabric used to weave the image of Lithuanian society that was being formed mythological figure. Palemon's descendants are described as skilled soldiers, who took up arms for three reasons. One was the desire to extend their territory, another 
was defence, and the third was blood feuds, when the men of one family fought over a woman, for power, or revenge. This last reason even saw a monk take up arms, in the case of the son of Grand Duke Traidenis, who was insidiously killed by his brother. ${ }^{1}$ In describing military campaigns, special mention was made of dukes who had distinguished themselves in battle and received hoards of gold, silver, horses and other treasures, either as gifts or as war trophies, while also highlighting their moral values. The glorification of war and the honouring of ancestors who participated and distinguished themselves in battles was not exclusive to the nobility of the GDL: it can be considered a part of the mosaic of Europe's militaristic noble society. It is interesting to draw a parallel between the Lithuanian nobility and the aristocracy of Western Europe, which particularly honoured its ancestors who had taken part in the Crusades, thus creating a collective memory and forming their genealogical identity. The time, space and form of this comparison differs, but its method and essence are the same. In 1311, Jean de Joinville, the seneschal of Champagne, created an epitaph for his great-grandfather who had died in the late 12th century, where he carefully lists ancestors from his agnatic line who participated in the Crusades, noting that the lion depicted on the family coat of arms was granted to his grandfather by Richard I, with whom his great-grandfather had fought in the Third Crusade. ${ }^{2}$ When analysing examples of the Western tradition, it is also important to note that military glory was often more important than Christian values and provisions, which were so exalted by society at the time. According to Anthony F. D'Elia, one's origins and how 'old' one's blood was superseded a strict Christian historical approach. Therefore, it was more honourable to have Attila the Hun among one's ancestors than a devout but undistinguished Christian. ${ }^{3}$

When we talk about the Christian tradition, as the research by Sigita Maslauskaite shows, even St Casimir, the patron saint of

${ }^{1}$ Lietuvos metraštis: Bychovco kronika, translation, introduction and commentary by R. Jasas (Vilnius, 1971), p. 65; Полное собрание Русских летописей. Летописи Белорусско - Литовские. Летопись Рачинского, t. 35, ed. Н.Н. Улащик (Москва, 1980), p. 151.

${ }^{2}$ N.L. Paul, To Follow in their Footsteps. The Crusades and Family Memory in the High Middle Ages (New York, 2012), p. 9.

${ }^{3}$ A.F. D'Elia, 'Genealogy and the Limits of Panegyric: Turks and Huns in Fifteenth-Century Epithalamia', in: The Sixteenth Century Journal, Vol. 34, No 4 (Winter, 2003), p. 991. 
Lithuania, was depicted in 1600 as a king wearing the robes of a Roman soldier and holding a sceptre. According to her, saintly rulers are often depicted in iconography with militaristic attributes, thereby showing that their authority comes from God, while the 'un-canon-like' portrayal of St Casimir was due to the widespread tradition about his military miracles, by which he became a powerful defender of the state and the Catholic faith. ${ }^{4}$ Jolita Liškevičiene developed the significance of the Miles Christianus image in the culture of the GDL, stating that 'a soldier of Christ was an example of a perfect person from that period. ${ }^{5}$ The extension of the military aspect and its various forms of expression became widely entrenched in society, encompassing very different fields. Showing military symbols and signs of victory became particularly popular in the 17th century on the frontispiece and on the heraldry of special publications in honour of the nobility of the GDL. ${ }^{6}$ Take, for example, the special publication dedicated to Marcin Ogiński, the Castellan of Mstislavl. There is an angel in the illustration playing the trumpet above a mounted figure, with his army behind him, riding towards the enormous Ogiński Gates adorned with a ducal cap, as if alluding to a triumphal arch. The banners attached to the trumpet show which other associated families the Ogińskis wish to demonstrate their affiliation to. In these banners, we can recognise the Radziwiłl eagle with the Three Horns (Traby) coat of arms on its chest, the Chodkiewicz Gryf, the Šemeta Swan, the Sanguszko Vytis (the Lithuanian mounted knight), the Pac Double Lily, the Tyszkiewicz Crescent with a star over it, the Połubiński Eagle with a horseshoe and a cross on its chest, the Naruszewicz Two Fish (Wadwicz), etc. ${ }^{7}$

\footnotetext{
${ }^{4}$ S. Maslauskaitè, ‘Šv. Kazimieras karys’, in: Kaip tai atsitiko didžiajame mūšyje... Žalgirio atodangos: tarptautinès parodos katalogas (Vilnius, 2010), pp. 121-124.

${ }^{5}$ J. Liškevičienè, Mundus emblematum: XVII a. Vilniaus spaudiniu iliustracijos (Vilnius, 2005), p. 71.

${ }^{6}$ A number of examples have been published: J. Liškevičienè, XVI-XVIII amžiaus knygu grafika: herbai senuosiuose Lietuvos spaudiniuose (Vilnius, 1998).

${ }^{7}$ Meta in porta virtutis et glorice Oginsciance: nec non Triennalis philosophice ... sub ... auspiciis ... Martiani ... Oginski ... publica disceptatione terminatce / a ... Luca Alexandrowicz ... præside ... Christophoro Eynarowicz ... (Vilnæ, 1703). For more, see: A. Railaitè-Bardè, 'Oginskių genealoginès savimonès atspindžiai XVII-XVIII a. proginiuose leidiniuose', in: Kunigaikščiai Oginskiai Lietuvos istorijoje. Kultūrinès veiklos pédsakais - 2, ed. R. Šmigelskytė-Stukienè (Vilnius, 2015), pp. 35-56.
} 
Genealogical awareness in the GDL is a topic of growing interest among researchers in this field. ${ }^{8}$ As a result, the historiography is becoming richer. One of the more relevant works is the article by Rimvydas Petrauskas about the conditions for and the beginnings of genealogical awareness in Lithuania in the 14th to mid-16th centuries. The author notes that in the 15 th to early 16 th centuries, a trend emerged among the nobility to stress the agnatic line of succession, which was oriented towards the past, leading to the birth of historic and genealogical awareness. ${ }^{9}$ Research dedicated to an analysis of genealogical awareness among the nobility who were not part of the social elite in the GDL is considered valuable to GDL historiography. The study by Kęstutis Gudmantas is important in that the author looked at the chronicles of Bielski and Stryjkowski, where the chroniclers encouraged an interest in the campaigns of ancestors, and the importance to one's genealogical and historical awareness of reading ${ }^{10}$. One of the latest works to analyse issues of the genealogical memory is the doctoral dissertation

${ }^{8}$ А. Райлайце-Бардзе, 'Генеалагічная свядомасць Сапегаў і яе адлюстраванне ў геральдыцы', in: Arche 3(148) (Минск, 2016), pp. 324-350; A. Railaitė-Bardè, 'Klèjos, Mnemosinès ir Atėnès dirbtuvių baruose: Ką atskleidžia Lietuvos Didžiosios Kunigaikštystès kilmingųjų genealoginiai medžiai ir schemos?', in: Dailès kūrinys istorijos šaltinis, ed. S. Smilingytè-Žeimienè (Vilnius, 2016), pp. 77-101; J. Drungilas, 'Pamirštos kilmès labirintuose: Nagurskių giminès atvejis XVIII a. antrojoje pusejje', in: XVIII amžiaus studijos, t. 2, ed. R. Šmigelskytė-Stukienè (Vilnius, 2015), pp. 221247; A. Railaitè-Bardè, 'Lietuvos Didžiosios Kunigaikštystės kilmingujų genealoginès savimonès XVI-XVIII a. legendinis ir sakralinis aspektai', in: Ministri historiae. Pagalbiniai istorijos mokslai LDK tyrimuose. Moksliniu straipsniu rinkinys, skirtas dr. Edmundo Rimšos 65-mečio sukakčiai, eds. Z. Kiaupa, J. Sarcevičienè (Vilnius, 2013), pp. 45-63; A. Railaitè-Bardè, Lietuvos Didžiosios Kunigaikštystès kilminguju genealogine savimone ir jos atspindžiai heraldikoje XVI-XVIII a. PhD dissertation (Vilnius, 2013); A. Railaitè, 'Šveikauskų genealoginè savimonè', in: Istorijos šaltiniu tyrimai, t. 4 (Vilnius, 2012), pp. 187-204; J. Drungilas, 'Adaptacja i integracja pierwszego pokolenia szlachty polskiej osiedlającej się na Żmudzi (II połowa XVI początek XVII wieku)', in: Europa Orientalis. Studia z dziejów Europy wschodniej i państw Bałtyckich t. 1, (Toruń, 2009), pp. 255-277; J. Drungilas, 'Etnosocialinis mobilumas Lietuvos Didžiojoje Kunigaikštysteje: Gruževskiu giminès pavyzdys (XVI a. antroji pusė - XVIII a. pradžia)', in: Lietuvos istorijos metraštis, 2004/2 (2005), pp. 53-78.

${ }^{9}$ R. Petrauskas, 'Atrandant protevius: genealoginio mąstymo prielaidos ir užuomazgos Lietuvoje XIV-XVI a. viduryje’, in: Ministri historiae pp. 45-63.

${ }^{10} \mathrm{~K}$. Gudmantas, 'Žemaičių bajoro ịrašai Martyno Bielskio Viso pasaulio kronikoje', in: Lietuvos Didžiosios Kunigaikštystès kalbos, kultūros ir raštijos tradicijos, ed. S. Temčinas [et. al.] (Vilnius, 2009), p. 38. 
by Jonas Drungilas about the integration of the Polish nobility in Žemaitija (Samogitia) in the 16th to 18 th centuries. ${ }^{11}$ Nonetheless, the memory of soldiers as ancestors is a research topic that, as a primary research object, has so far received very little attention in GDL historiography.

Research conducted in recent years ${ }^{12}$ about the genealogical awareness of the nobility in the GDL involved studying over 160 families, 48 of which exhibited a military aspect in their genealogical awareness, that is, their genealogical awareness was based on the representation of legendary or actual ancestors who could boast of military distinctions. Going to war was one of the fundamental duties of an individual of noble status, and an expression of honour and power. The reputation of a famous soldier or commander was very important in the glorification of the nobility in the GDL. The military aspect is especially important to the genealogical awareness of certain nobles, which is understood as the self-identification of nobles in the genealogical aspect in their lifetime and their space, and the information the nobility had about their ancestors. Identity could be constructed based on this information. Families would often choose legendary or actual ancestors who had gained distinction in war to be represented in their genealogy. Therefore, we can say that these kinds of families had a militaristic genealogical awareness.

In this article, we shall try to show how the manifestation of ancestors who were distinguished in war was expressed in the genealogical awareness of the nobility in the GDL, using 17th and 18th-century publications to mark special occasions, genealogical trees and diagrams. We discuss what position the glorification of certain battles took in the genealogical memory of the nobility in the GDL, bearing in mind the context of one of the most famous battles that the GDL took part in. We try to ascertain what memories of specific battles and soldiers who fought in them, in the genealogical sources mentioned, are important to the genealogical awareness of the nobility in the GDL, and why this memory is so

${ }^{11}$ J. Drungilas, Lenku bajoru integracija Žemaitijoje: migracija, kalba, atmintis XVI-XVIII a. PhD dissertation (Vilnius, 2018).

${ }^{12}$ Cf. A. Railaitė-Bardè, Lietuvos Didžiosios Kunigaikštystès kilmingujų. As part of the dissertation, 115 noble families in the GDL were analysed, and this number has now grown to 160 . 
selective; that is, why some battles and distinguished heroes are remembered and glorified, while others are not. Could it be that the same happened with the Battle of Orsha, one of the most famous battles after the defeat of the Teutonic Knights at the beginning of the 15th century, as happened with the Battle of Grunwald? Did Orsha become an episodic trigger in the genealogical memory of the nobility in the GDL? What memories of battles were important to the genealogical representation of certain families, how was it expressed, and in which period were the ancestors who participated in this battle remembered?

The first part of this study presents the memory of an ancestor as a soldier in a general sense, and the ways this memory was expressed. The second part focuses on ancestors who earned distinction in specific battles, and identifies in which battles participating members were remembered and glorified, thereby distinguishing them from other members of the family.

I.

The memory of ancestors of the nobility of the GDL who distinguished themselves in military activity was manifested in genealogical trees and diagrams, and in publications to mark special occasions, and was expressed in two ways: in written and visual form.

In the 17th century, Stanisław Xawery Rodkiewicz wrote a special publication, an epithalamium, to mark the wedding of Jan Skorulski, the son of the Kaunas marshal, to Ludwika Ciechanowiecka, the daughter of the GDL master of the camp. ${ }^{13}$ In it, he described members of the Ciechanowiecki family, and those linked to them through marriage, who had important duties in the GDL, as chancellors, voivodes and hetmans. Jan Karol Chodkiewicz received particular attention. He was referred to as Hercules, a very popular mythical hero of Ancient Greece and Rome. Exceptional magnates and rulers,

${ }^{13}$ S.X. Rodkiewicz, Szczęsliwy lot strzaty w herbow na Dąmbrowe albo fortunne dwuch przeswietnach domow spowinowacenie przy weselnym akcie... Jana... Skorulskiego marszalkowica kowie[n]skie[go] z... Ludwika... Ciechanowiecka... I przez Stanisła Xawerego Rodkiewicza... na tymże akcie weselnym... oblubiencom offiarowany (Vilnae, 1683). See: XVII a. Lietuvos lenkiškos knygos, ed. M. Ivanovič (Vilnius, 1998), p. 137. For more, see: A. Railaitè, 'Jonas Skarulskis ir jo ryšiai su Kantakuzenais: Kauno maršalaičio vestuvių epitalamijo tyrimas', in: Istorijos šaltiniu tyrimai, t. 3 (Vilnius, 2011), pp. 153-166. 
such as Louis XIV ${ }^{14}$ and Cosimo de' Medici, ${ }^{15}$ were sometimes also given this name. Rafał Skorulski, the father of Jan Skorulski, was called the Greek Achilles or Hector. While these were also heroes from Antiquity, they were not of the same rank as Hercules. In Western Europe, the image of Hercules dominated both in literature to mark special occasions and in visual and monumental art. The figure of Hercules is also important in European history, because in the Middle Ages and the Renaissance he was considered the founding father of certain states, such as France (along with the myths of Troy and Clovis), ${ }^{16}$ Spain ${ }^{17}$ and Florence (together with Augustus). ${ }^{18}$ An aura of sacredness surrounded Hercules in Spain, because his popularity was based not just on his successes in Europe, but also because he was seen as the personification of virtue, even being identified with Christ as his allegorical precursor. ${ }^{19}$ More lines of text in the epithalamium are dedicated to describing the merits of Jan Karol Chodkiewicz, a distant relative, than to Jan Skorulski's own father Rafał.

The genealogical tree of the Korybut Wiśniowieckis in the second half of the 17 th century ${ }^{20}$ is depicted on a military banner carried by a cavalryman symbolising the Korybut Wiśniowiecki family. A military banner is a sacred attribute. In this way, the greatness of the Korybut Wiśniowiecki family is shown as being determined by the glorious military campaigns by members of the family. This is probably an allusion to Jeremi, the father of Michał Korybut Wiśniowiecki, who particularly distinguished himself in battles. Jeremi Korybut Wiśniowiecki studied the art of war in Holland, and was a notable fighter in the wars against Moscow and the Zaporozhian

${ }^{14}$ P. Burke, The fabrication of Louis XIV (New Haven, London, 1992), pp. 94, 167.

${ }^{15}$ R.J. Crum, "Cosmos, the World of Cosimo": The iconography of the Uffizi Façade', in: The Art Bulletin, Vol. 71, No 2 (Jun., 1989), pp. 237-238, 245, 251.

${ }^{16}$ R.E. Hallowell, 'Ronsard and the Gallic Hercules Myth', in: Studies in the Renaissance, Vol. 9 (1962), pp. 244-246, 250, 252, 255.

${ }^{17}$ L.F. Candelaria, 'Hercules and Albrecht Dürer's 'Das Meerwunder' in a Chantbook from Renaissance Spain,' in: Renaissance Quarterly, Vol. 58, No 1 (2005), pp. 15, 19, 35-38.

${ }^{18}$ Cf. R.J. Crum, “"Cosmos...”, pp. 246-249.

${ }^{19}$ Cf. L.F. Candelaria, 'Hercules..., pp. 15, 19, 35-38.

${ }^{20}$ The genealogical tree of the Korybut Wiśniowiecki family from the second half of the 17th century, AGAD, Nabytki 199, sygn. 359. The genealogical tree has been published in: M. Kałamajska-Saeed, 'Genealogia portretowa Sapiehów i jej twórcy', in: Sapiehowie epoki Kodnia i Krasiczyna, ed. K. Stępnik (Lublin, 2007), Appendix 9. 
Cossacks. ${ }^{21}$ Several special publications illustrated his victories. ${ }^{22}$ This composition could also symbolise the fact that a member of the Korybut Wiśniowieckis, a well-respected family which was linked through marriage to imperial and royal families in other countries, in this case probably Michał Korybut Wiśniowiecki, was a suitable defender of his land and a military commander. Flags are one of the most important symbols of a state. Their use can be traced back to Antiquity, when the Romans used flags, along with other military symbols, not only for practical purposes, but also to boost morale. The flag was considered to be sacred, and would be kept in a shrine in times of peace, while the loss of a flag would be shown by a mark on one's escutcheon. ${ }^{23}$ The significance of the flag and rituals associated with it became especially popular in the Middle Ages. For example, the oriflamme (golden flame), a red silk flag with golden stars, played a very important role in France. It was not only a sacred and highly respected symbol of the state, but was also a royal emblem. ${ }^{24}$ At the beginning of the 13th century, it was believed that the oriflamme was carried by Charlemagne himself during a campaign against the Saracens: the vision allegedly appeared in a dream to the Emperor Constantine. During the reigns of Charles V and Charles VI (1364 to 1422), a ceremony to consecrate the oriflamme developed that lasted a whole day and night. It would be performed before and after an important military campaign. The oriflamme was blessed by St Denis, the first Bishop of Paris, a martyr and patron saint of France, 'to defend the faith and the

${ }^{21}$ K. Niesiecki, Herbarz Polski, t. IX (w Lipsku, 1842), pp. 353-354.

22 J. Białobucki, Pochodnia woienney sławy Iaśnie Ożwieconego Książęcia I. M. Ieremia Michała Korybuta na Wiżniowcu i Łubniach Wiśniowieckiego: ze czterech część w roku 1648 złożona (w Krakowie, 1649); idem, Pogoda iasna Oyczyzny, w ktorq okazały się y nagrodę biora wysokie zastugi, a nie zaćmiona sława Jaśnie Oświeconego Kśiązęćia Jego Mośći Ieremia Michała Korybuta na Wiśniowcu y Eubniach Wisniowieckiego, Woiewody Generała Ruskiego, Hetmana W. Koronnego, Przemyskiego, Przaśniskiego, Kaniowskiego, \&c. Starosty, Panegirikiem przywitana. Przez Urodzonego Iana Bialobockiego Krola I. M. Sekretarza, po Seymie Walnym Koronnym Warszawskim, w Roku 1650. zaraz na poczatku skonczonym. Ktory Panegiryk na cztery Częśći rozdźielony, y na świat Roku tegoż wydany (w Krakowie, 1650); Dvcis in Wisniewiec et Lvbnie Hieremice Michaelis Koribvt Palatini Russice Gubernatoris Kaniouiensis \&c. \&c. Contra Cozacos Zaporouios A. 1648. gesta compendiarò narrata. A.V. Kojalavičius, De Rebvs Anno 1648. \& 1649. Contra Zaporovios Cosacos Gestis (Vilnæ, 1651); M. K. Szemet, Przeważnych wojennych dziełach wielkiego rycerza księcia Jeremiego Michała Korybut Wiśniowieckiego, 1644.

${ }^{23}$ Antikos žodynas (Vilnius, 1998), p. 235.

${ }^{24}$ J.-P. Roux, Karalius. Mitai ir simboliai (Vilnius, 2007), p. 221. 
kingdom'. ${ }^{25}$ In Christian iconography, we can see the resurrected Christ with a flag, a symbol of sacredness and triumph, as well as the lamb and saintly warriors, such as Joan of Arc, St George and John of Capistrano. ${ }^{26}$ In this way, the flag bearer, and in particular the flag depicted in the illustration of the Korybut genealogical tree, is a symbol of the Korybut family's military glory, honour, trust, and ability to valiantly lead their country.

The genealogical awareness of the nobility in the GDL consisted of various aspects, which would often be closely related to one another. We know this from the example of the Pac family, another Lithuanian magnate family. The legendary aspect of their genealogical awareness intertwines with the military aspect. In a genealogical diagram of the Pac family from the 18 th century, ${ }^{27}$ the nobles' legendary ancestors are depicted along the bottom in large separate circles which are not incorporated directly into the diagram. Even though we can see that the complete genealogy of their legendary ancestors is known, we learn from the information presented which story of the family's origins is alive in the Pac genealogical awareness. Their genealogical diagram states that 3,995 years since the creation of the Earth, Cosmus Pacius, the Consul Romanus Pontifex Maximus, came to Lithuania from Rome after the Battle of Pharsalus, fearing Julius' wrath, together with his close relatives Palemon Publius, Prosperus Cezarinus Columnus, Dausprungas, and others. His grandson Warra Pacius was Duke of Etruria, also known as Florence, who created a family in the GDL, but also left successors in Etruria. His greatgreat-grandson Marcus Pacius was the Voivode of Trakai after the capital was transferred from Trakai to Vilnius during the reign of Gediminas in 1322. Another two ancestors of the Pac family (who are also not incorporated directly into the genealogical diagram) are depicted in large highlighted circles (on the left and right of the diagram). They are Wilhelm Pac, the military commander of King Godfrey of Jerusalem, and his brother Stefan Pac.

The military aspect in genealogical awareness is not uncommon in other noble families in the GDL either. A special publication in honour of Simeon Samuel Liubartowicz Sanguszko pays particular

${ }^{25}$ C. Beaune, The Birth of an Ideology. Myths and Symbols of Nation in LateMedieval France (Berkeley, Los Angeles, Oxford, 1991), pp. 53-55.

${ }^{26}$ H. Biedermann, Naujasis simboliu žodynas (Vilnius, 2002), pp. 474-475.

${ }^{27}$ Genealogical diagram of the Pac family from the 18th century, Manuscript Department of the Wrublewski Library of the Lithuanian Academy of Sciences (LMAVB RS), f. 20-6514. 
attention to the military glory of the Sanguszko family. ${ }^{28}$ Roman Liubartowicz Sanguszka, the Voivode of Breslau and Great Hetman of Lithuania, and one of Simeon Samuel's ancestors, who is referred to as the second Hercules and second Belisarius, is very highly exalted, 'ferociously taking castles from enemy hands, crushing whole enemy regiments with his strong and fearless spirit, who received his title from Ramove, as chroniclers have lauded, cutting down nine thousand Muscovite soldiers in a bloody battle, where only twenty of his men fell, and thirty were injured' ${ }^{29}$ Mention was made of his glorious military reputation in several special publications. Another epithalamium from the 17th century, dedicated to Karol Stanisław Radziwiłł and Anna Katarzyna Sanguszko, about an ancestor of the bride who lived in the 16th century, says: 'This glorious Hercules of Lithuania, a sworn enemy of his homeland's enemies the Muscovites and Tartars, entwines palms of triumph into the victorious trophies of the Radziwiłłs.' ${ }^{30}$ The mother of Karoł Stanisław Radziwiłł was Katarzyna Sobieski, the sister of John III Sobieski, the King of Poland and Grand Duke of Lithuania. The fact that her father Jakub Sobieski was also a recipient of such dithyrambs is evident from the following invocation: 'Most illustrious Jakub Sobieski, o ye most eloquent and coveted Nestor of Sarmatia, with the sighs of Heaven'. ${ }^{31}$

There were more such Nestors and Hercules in the GDL. Pawel Karp was known by one of these eminent names, while the title of the Sarmatian Hercules was bestowed upon Jan Karp. Interestingly, these figures are remembered in a panegyric dedicated to the Bishop

${ }^{28}$ T. Dygon(ia), Przemiana koni poszonycz pod lektyke Jaśnie Oświecone Xiążęcia Jego Mści Simeona Samvela Lvbartowicza Sanguszka y Kowła woiewody Witepskiego starosty Suraszkiego..., Zakonu Franciszkas. Deobservantia gvardzana konwentv Orszanskiego, 1639.

${ }^{29}$ Ibid. (pages are not numbered): ktory zamki potężne / z rąk nieprzyiaćiot pogranicznych szżęśliwie odbierat / ktory potężnym y nie przestraszonym Animuszem swoim straszne putki nieprzyiaćielskie gromit / ktory iako kroiniki opiewaia / na uroczysku nazwanym [...] dżiewięć tyśięcy Moskwy na krwawym boiowisku położyt I a iego zabitych tylo dwanaśćie, rannych zaś trzydżieśći zostało [...].

${ }^{30}$ Carolvs Magnvs Generis, Virtutis, Sapientice \& Glorice Magnitvdine Svam Proponens Maiestatem Ad Plausum Dvcalis Hymencei Celsissimi \& Illustrissimi S. R. I. Principis Caroli Stanislai Radziwit Ducis in Otyka \& Nieświez, Comitis in Szydłowiec, Mir, Kroże, \& Biała, Procancellariji M. D. L. Prcemysliensis, Camenecensis, Krzyczeviensis \&c. \&c. Gubernatoris, Nec non, Celsissimce \& Illustrissimce Principis Annce Catharince Sangvszkowna Ducissce in kowel Atque Smolany Publicis Orbis Poloni Lituaniq[ue] obtutibus Propositus (Vilnae, 1692).

${ }^{31}$ Ibid. 
of Samogitia in $1737 .{ }^{32}$ We can see that even in special publications in honour of senior members of the Church, where usually their spiritual qualities would be strongly accentuated, the authors also took the opportunity to boast of famous members of their family who were glorious in war.

If we return to the epithalamium dedicated to Karoł Stanisław Radziwiłł and Anna Katarzyna Sanguszko, we should note that a marriage to a female member of a famous family could create a need to recall a ruler of Lithuania from even further back in the past, the Lithuanian grand duke referred to as the Macedonian of Lithuania in a special publication. Without doubt, the authors wished to make an allusion to the particularly large territory that belonged to the GDL at that time (or in common parlance in those days, 'from sea to sea'). In this way, the achievements of Vytautas the Great are compared to the empire of Alexander the Great, his enormous territory extending over the Balkan Peninsula, Egypt, Persia, and the upper reaches of the Indus. This source is also especially noteworthy because it is precisely Vytautas who is mentioned. Sources reflecting the genealogy of the nobility of the GDL, from the Gediminids it is either Gediminas himself, or his sons Algirdas or Jogaila, are usually mentioned. One of the most famous Lithuanian rulers, along with the Battle of Grünwald, is basically overlooked in the period analysed. This can be explained by the fact that Jogaila was the patriarch of the Jagiellon dynasty, whose members were monarchs of several European states, whereas Vytautas had no descendants in the male line, and was never crowned king, despite being quite a spectacular ruler.

The military aspect of genealogical awareness is not only characteristic of the aristocracy, but also of lower-ranking families. One example is the Bułharyn family. The military aspect in the genealogical awareness of the Bułharyn family is quite pronounced, as it is accentuated even when referring to patriarchs of the family. A sermon written for the funeral of Tomasz Butharyn, the deputy cupbearer of the Voivode of Navahrudak, says that his family originated from Bulgaria, a kingdom with famous heroes who fought valiantly against its enemies, of which the first to be mentioned should be the Byzantine Emperor Constantine IV the

${ }^{32}$ Ceelum Sidereum Gloriâ Stellarum terras Jlluminans : terno aviti Stemmatis Sydere ... Josephati Karp Episcopi Samogitice Jllustratum, nec non Sacrâ Consecrationis Luce Syderum Suorum Domino Consecratum (Vilnae, 1737), p. H2. 
Bearded (668-685). The publication mentions that once he was defeated, many of his lands were captured. The source glorifies the triumphant victories of the Butharyn family over other Byzantine emperors, such as Justinian II the Rhinotmetos (685-695 and 705-711), Constantine VII the Purple-Born (913-959), and Andronicus II Paleologus (1282-1328). ${ }^{33}$

II.

According to the sources gathered for this study (genealogical trees, genealogical diagrams and special publications) that show the military aspect in the genealogical awareness of certain families in the GDL, the ancestors who fought against the Russians, Swedes or Turks were glorified.

Nine aspects can be distinguished in the genealogical awareness of the nobility in the GDL; that is, the nobility would look back at their ancestors through a particular prism, thereby selecting which ones should be remembered and glorified, and which ones should inadvertently be 'forgotten', in order to construct a genealogical memory that was as favourable as possible, and also creating an identity for the nobility. All this was intended to establish their status in society. The nine aspects of genealogical awareness of the nobility in the GDL are as follows: legendary, sacred, agnatic, sword and distaff, rank/duty, confessional, militaristic, material/landowning, and founding (churches and the like). With this in mind, we can say that the memory of various famous noble ancestors was associated with a strong genealogical awareness. Of the 48 noble families of the GDL that exhibited a military aspect in their genealogical awareness, 18 families featured three aspects of genealogical awareness in total, ten families featured four aspects, three featured five aspects, and another ten featured six or seven aspects of genealogical awareness. Only a few families exhibited one or two aspects of genealogical awareness,

${ }^{33}$ A. Woyzbun, Kazanie pogrzebowe Przy złożeniu ciała ś. p. Wielmożnego Jmći Pana Tomasza Bułharyna Podczaszego Wojewòdztwa Nowogrodzkiego W Kośćiele Wotkowyskim Societatis Jesu Roku Pańskiego 1759. Dnia 30. Pazdźiernika Miane A ná uśilne żądania Wielmożney Jeymośći Pani Anny z Jelskich Bułharynowey Podczaszyney Nowogrodzkiey, pozostałey Malżonki Tudźież Wielmożnych Ichmośćiow Panow Pawła Koniuszego Wołkowyskiego, Regenta Skarbu Wielkiego Xięstwa Litewskiego Jozefa Starosty Bakuńskiego Kazimierza Porucznika Regimentu Konnego, Buławy Polney W. X. Litewskiego Michała Podczaszyca Nowogrodzkiego Bułharynow, Imienia Oycowskiego Dźiedźicow do Druku podane, Y Onymże Ofiarowane (w Wilnie, 1760), pp. E2v-Fr. 
including the militaristic one. Therefore, it can confidently be said that the more developed the genealogical awareness of a noble family, the greater the likelihood that these nobles would remember/'discover' ancestors in whose military brilliance subsequent descendants could bask. It can be stated that the military aspect of genealogical awareness was one of the four most popular aspects (the other three being sword and distaff, rank/duty, and material/landowning). It should be added that the military aspect was expressed most in the genealogical awareness of the nobility in the GDL in the 17th century. We notice a significant increase in the written culture, and a consolidation of historical and genealogical awareness, from this time. ${ }^{34}$

Without necessarily quoting each description in which ancestors of noble families who distinguished themselves in famous battles are glorified, we can take as an example Eustachy Tyszkiewicz, the Vovoide of Mstislavl, a reborn Hercules, hero of the Battle of Khotyn, who fought against the 'Ottoman hydra' ${ }^{35}$ In literature to mark special occasions in the 18th century, the Zawisza are also identified as famous battle heroes: Eustachy distinguished himself fighting the Swedes, while Gregorz distinguished himself at Khotyn. ${ }^{36}$ The Battle of Ula in 1564, when a significantly larger Muscovite army was defeated, is also not overlooked in early writings. Grigalius Kisielius fought bravely under the banner of Grzegorz Chodkiewicz, whose mother was from the Tryzno family. ${ }^{37}$ The member of the Kisielius family is remembered in the context of another battle as well. A special publication from 1635 claims that 'grandfather [...] Kisielius, born in Moszczanka, on the field of Mars near Orsha, in that famous battle, a member of the court of Sigismund the Old, the King of Poland, and an infantryman in the regiment of the eternally remembered hetman Duke Ostrogski, did indeed fight with glory. ${ }^{38}$

${ }^{34}$ Cf. A. Railaitė-Bardè, Lietuvos Didžiosios Kunigaikštystès kilminguju genealogine, pp. 138-143.

${ }^{35}$ R. Jączyński, Erectia plánetow Tyszkiewiczowskich: albo Krotkie Kazánie ná Pogrzebie ... Iana Eustachivsza Tyszkiewicza, Woiewody Brzesckiego, Kámienieckiego ... (w Lvblinie, 1637).

${ }^{36}$ J. Rudamina, Gryphus Coronarij Auri Custos Non minùs Sapientiâ ... / Ab Illustrissima, Prcenobili, ac Magnifica Iuventute Almce Academice et Vniversitatis Vilnensis Societatis Iesv [i.e. J. Rudamina] Propositus Anno auream Mundo cetatem inferentis DEI 1714. Kalendis Augusti. - 1714.

${ }^{37}$ C. Коссов, Патєрıкоv abo źywoty ss. oycow Pieczarskich obszyrnie stowieńskim ięzykiem przez świętego Nestora zakonnika y latopisca Ruskiego przedtym napisany (w Kiiowie, 1635), p. A3v.

${ }^{38}$ Ibid. 
This can be considered a written example of genealogical memory concerning the Battle of Orsha expressed by the nobility of the GDL. In what other ways could this kind of memory be expressed?

The frontispiece (Fig. 1) of a special publication dedicated to Janusz Skumin Tyszkiewicz in 1641 depicts a crescent with an eight-point star in the foreground (the Leliwa coat of arms of the Tyszkiewicz family), with the most famous member of this family supported by an angel and a soldier in armour, who appear to be shield-bearers. Shield supporters are usually passive figures in coats of arms, who only support or hold the shield. In this case, it is important to note the soldier, who is not only holding the crescent with his right hand, but is also standing on another crescent lying on the ground, and piercing the chest of a two-headed crowned eagle with the sword in his left hand. ${ }^{39}$ The crescent is a symbol of the Ottoman Empire, while the two-headed crowned eagle symbolises the Russian Empire. In this way, the shield-bearer in armour symbolises members of the Tyszkiewicz family who fought against the Muslims and the Russians. These images highlight the military distinction of these magnates, and also accentuate the military aspect of their genealogical awareness. The military aspect in heraldry is not so often expressed, unless we count Baroque clichés such as the ornate decoration of military coats of arms. Therefore, it is even more important to stress the mentioned genealogical illustration of Janusz Skumin Tyszkiewicz from 1641, in which the inclusion of the shield supporter in the family coat of arms is obviously an expression of the military aspect of the Tyszkiewicz family's genealogical awareness. Even though this source is very telling, it still does not show whether piercing the two-headed eagle symbolising Russia with a sword is an allusion to a specific battle against Moscow, or if battles against the Russians in general were depicted using these artistic means. We could try to solve this riddle. A possible answer could lie in family ties. Aleksandra, the daughter of Vasilii Tyszkiewicz, the Voivode of Smolensk, had three husbands. Her first two are of more interest to us: Aleksandr Chodkiewicz, the Castellan of Vilnius, and Konstanty Ostrogski, the Deputy Cupbearer of Lithuania. ${ }^{40}$ This woman from the Tyszkiewicz

${ }^{39}$ Phaenomena, seu aspectus felicissimi syderum ... Ianussi Skumin Tiszkiewicz, palatini Vilnensis ... primo ... eiusdem ingressu in palatinatum Vilnen[sem] observata. Ab Alberto Izdebski, artium et philosophiae baccalaureo, s. theologiae auditore in al [ma] Acade[mia] Vil[nensi] S. I. proposita ... (Vilnae, 1641), frontispiece.

${ }^{40}$ W. Dworzaczek, Genealogia (Warszawa, 1959), Table 177. 


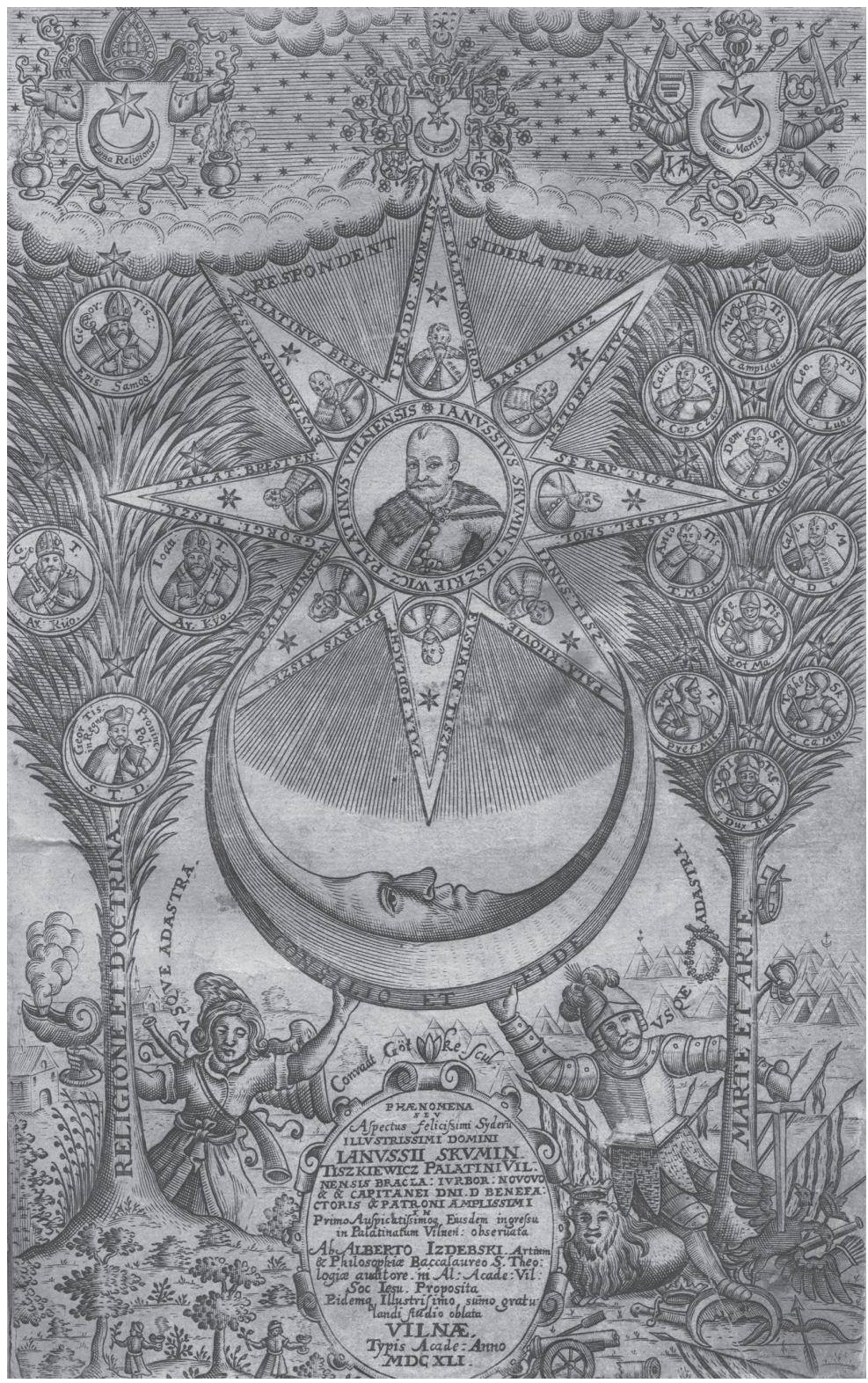

A Frontispiece in a Commemorative Publication Dedicated to Jonušas Skuminas Tiškevičius in 1641.

Source of illustration: Phaenomena, seu aspectus felicissimi syderum... Ianussi Skumin Tiszkiewicz, palatini Vilnensis, ... primo... eiusdem ingressu in palatinatum Vilnen[ sem ] observata. Ab Alberto Izdebski, artium et philosophiae baccalaureo, s. theologiae auditore in al[ ma ] Acade[ mia ] Vil[ nensi ] S. I. proposita... (Vilnae, 1641). 
family was a link between the Tyszkiewicz, Chodkiewicz and Ostrogski families. As a result, military triumphs could also be shared. We can assume that the soldier on the frontispiece who is standing on the crescent and piercing the chest of the two-headed crowned eagle with his sword might be an allusion to the ancestors of Janusz Skumin Tyszkiewicz from the Chodkiewicz and Ostrogski families, even though they are not direct blood relatives. If this assumption is correct, we can make a second assumption: that this kind of artistry was also used to mark the battles of Orsha (1514) and Khotyn (1621), which both ended in victory for Lithuania.

Nonetheless, the names of separate battles in special publications (the military aspect of the genealogical awareness of the nobility of the GDL is barely reflected in genealogical trees and diagrams $)^{41}$ seem to disappear when they are referred to generally as battles against Muscovy, the Swedes and the Turks (or Tartars). For example, a special publication from 1680 mentions that Bohdan Ogiński, the Deputy Chamberlain of Trakai, was feared by Muscovy, the Swedes and the Turks. ${ }^{42}$ Another case could be the Sanguszko family, who in the first half of the 17th century recalled the 16th-century Field Hetman of Lithuania Roman Sanguszko as follows: 'the Field Hetman of the Grand Duchy of Lithuania Roman Sanguszko is alive in our stories with his great, glorious victories against Muscovy and the Tartars. ${ }^{43}$ It could also be assumed that heroes in battles against the Tartars could have been honoured for ideological reasons, for having defeated non-Christians, even though the religious aspect is not emphasised in descriptions of military distinctions of specific ancestors.

Of all the sources collected and analysed for this research, only one was found to mention the Battle of Grünwald. This should not come as a surprise, bearing in mind the lack of memoirs from the second half of the 16th century to the 18th century about this important victory. Apart from Maciej Stryjkowski and Albert Wijuk

${ }^{41}$ Apart from the points mentioned in this article, the military aspect was reflected, albeit rarely, through the military dress of ancestors illustrated in genealogical trees; specific inscriptions in the genealogical tree associated with war were even rarer. For more, see: Cf. A. Railaite, 'Šveikauskų...', pp. 187-204.

${ }^{42}$ M. Woyniłowicz, Snieg ogien / przez x. Michała Woyniłowicza s. th. doktora prowincyała prowincyey Litewskiey ... w Wilnie roku 1680. dnia 5. Novembra ... ogłoszeni. 1680.

${ }^{43}$ A. Mokrski, Pogonia żałobna Jasnie Oswieconego, y Jaśnie Wielmożnego Páná Symeona Samuela Lubartowicza Sanguszka, xćiá z Kowla, woiewody Witepskiego, stárosty Suraskiego, etc. etc., v grobu zastanowiona / przez x. Andrzeia Haczla Mokrskiego, theologá Societatis Iesu. Roku 1639. dniá 22. Lutego (w Wilnie, 1639). 
Kojałowicz, just a handful of authors from this period, including Ioannes Radvanus and Samuel Dovgird, only episodically described the great battle in their work, or heroic campaigns would sometimes become a source for apotheosis when documenting the heroism of the ancestors of the nobility. The Battle of Grünwald was a historic event that unified Poles and Lithuanians; however, its significance was overshadowed by the problematic relations of the Polish-Lithuanian Commonwealth with Russia, Sweden, and the Ottoman Empire, which is why the battle which crushed the Order "no longer held an additional stronger political connotation'. ${ }^{44}$ This circumstance determines the even greater interest in rare sources in which Grünwald actually is mentioned. One source is the special publication dedicated to the Kierla family of $1652 . .^{45}$ Ludwig Kierla, the great-grandson of the Elder of Grembov, and a member of the family to whom Sigismund the Old granted indigeneity, was the son of Dacbog Kierla and Kristina Valavičiūtè. He only moved to Lithuania in the middle of the 17th century, when his mother entered into a second marriage with Michał Tryzno, the Grand Treasurer of Lithuania. He sold the domains he had inherited from his father in Misterwald, Opalin and elsewhere in the Voivodeship of Pomorie. In Lithuania, he married Krzysztof Kiszka, the daughter of the Voivode of Vitebsk, who was the niece of Janusz Kiszka, the Grand Hetman of Lithuania, with whom he had two children, Kazimierz and Joanna. ${ }^{46}$ Michał and Ludwig Kierla, the ancestors of this Kierla, who were killed along with 50,000 Teutonic knights at the Battle of Grunwald against Jogaila on 15 July 1410, had settled in Lithuania. ${ }^{47}$ As researchers of the Battle of Grunwald have stated, this number of fallen soldiers comes from the chronicle by Jan Długosz (which is also mentioned in the work of Maciej Stryjkowski), which had a major influence on writing in Poland and Lithuania. ${ }^{48}$

${ }^{44}$ D. Mačiulis, R. Petrauskas, D. Staliūnas, Kas laimèjo Žalgirio mū̌ṣ̌i? Istorinio paveldo dalybos Vidurio ir Rytu Europoje (Vilnius, 2012), pp. 37-38, 40.

${ }^{45}$ W. Tylkowski, Antiqvitas Gentilivm Armorvm Illvstris Kierloviance Domvs Ex Antiqvissimis Privilegiis Imperatorvm, Ac Regvm Ervta Vna Cvm Magnis Hvivs Domvs Heroibvs Reprcesentata Illvstri Ac Magnifico Domino D. Gabrieli Kierto ... Ab Alberto Alexandro Paprocki Gente Iastrzebecio, 1652.

${ }^{46}$ Ibid., p. H/25-Hv/26.

47 'Michał y Ludwik młodszy Braćia iego przy Krzyżakach zostawszy / w oney pamiętney bitwie z Jagellem Krolem Anno 1410. die 25. Iulit na Grynewaldźie przy wśi Panenberk Rycerstwo polegli / z piąciądźiężiąt tysięcy inszych Pruskich Krzyżakow teste Cromero lib. 16.'. See: Ibid, p. G/21.

${ }^{48}$ Cf. D. Mačiulis, R. Petrauskas, D. Staliūnas, Kas laimẻjo Žalgirio mūšị? , p. 38. 


\section{Conclusions}

1, The military genealogical awareness of the nobility of the GDL, expressed in genealogical trees and diagrams and special publications from the 17th and 18th centuries, is reflected in written and visual forms. The latter appear very rarely, and even though the information is encoded in symbols, it is no less important than the glorification of the ancestors of Lithuania's nobility conveyed in writing.

2 , We can assume that the victory at Orsha, known as the second Grunwald, was recalled by the nobility of the GDL, but faded somewhat in comparison with the battles of Kircholm and Khotyn. Among the ancestors of various noble families of the GDL, the mention of Jan Karol Chodkiewicz, a hero of both these battles, was preferred over Konstanty Ostrogski. This could be due to various factors. Chronologically, the Battle of Orsha occurred much further back in time than the battles of Kircholm and Khotyn. In addition, by the 17th and 18th centuries, we can already speak about a genealogical awareness of the nobility in the GDL having formed, which was closely related to their historical awareness. It was just in its early stages in the 16th century. Written culture flourished much more prominently in the 17th and 18th centuries. As a result, conditions were more favourable for recalling events and famous figures, and if required, to revise the accounts of one's origins in the right direction, and to pass this knowledge on to future generations.

3 , The military aspect of genealogical awareness is characteristic of both the higher nobility and lower-ranking nobles in the GDL who could boast of a strong genealogical awareness. The genealogical awareness of the nobility in the GDL in the 18th century, and especially in the 17th century, can truly be called triumphalist, as the military aspect of genealogical awareness was one of the four most popular aspects among nobles. However, the main victories adorning the triumphal arch of genealogical awareness among the nobility in the GDL were those of Kircholm and Khotyn, rather than Grunwald and Orsha.

Author Details

Agnè Railaite-Barde is a doctor of humanities working in the Department of the History of the Grand Duchy of Lithuania at the Lithuanian Institute of History. She is also the chair of the Lithuanian Heraldry Commission, and an associate member of the International Academy of Heraldry. Her main academic fields of interest are the heraldry and genealogy of the nobility, comparative research into 
the nobility's genealogical awareness and variations in it in the Grand Duchy of Lithuania and other European countries in the 16th to 18th centuries, and Lithuanian state and municipal heraldry.

Address: Lithuanian Institute of History, 5 Kražių St, Vilnius LT-01108, Lithuania E-mail: agnerailaite@gmail.com

\section{Bibliography}

Antikos žodynas (Vilnius, 1998).

BEAUNE, Colette. The Birth of an Ideology. Myths and Symbols of Nation in Late-Medieval France, (Berkeley, Los Angeles, Oxford, 1991).

BURKE, Peter. The fabrication of Louis XIV (New Haven, London, 1992).

CANDELARIA, Lorezo F. 'Hercules and Albrecht Dürer's 'Das Meerwunder' in a Chantbook from Renaissance Spain', in: Renaissance Quaterly, Vol. 58, No 1 (2005), pp. 1-44.

CRUM, Roger J. 'Cosmos, the World of Cosimo': The iconography of the Uffizi Façade', in: The Art Bulletin, Vol. 71, No 2 (Jun., 1989), pp. 237-253.

D‘ELIA, Anthony F. 'Genealogy and the Limits of Panegyric: Turks and Huns in Fifteenth-Century Epithalamia', in: The Sixteenth Century Journal, Vol. 34, No 4 (Winter, 2003), pp. 973-991.

DRUNGILAS, Jonas. 'Adaptacja i integracja pierwszego pokolenia szlachty polskiej osiedlającej się na Żmudzi (II połowa XVI - początek XVII wieku)', in: Europa Orientalis. Studia z dziejów Europy wschodniej i państw Battyckich (Toruń, 2009), pp. 255-277.

DRUNGILAS, Jonas. 'Etnosocialinis mobilumas Lietuvos Didžiojoje Kunigaikštystèje: Gruževskių giminès pavyzdys (XVI a. antroji pusè XVIII a. pradžia)', in: Lietuvos istorijos metraštis 2004/2 (2005), pp. 53-78.

DRUNGILAS, Jonas. 'Pamirštos kilmès labirintuose: Nagurskių giminès atvejis XVIII a. antrojoje pusèje', in: XVIII amžiaus studijos, t. 2, ed. R. Šmigelskytè-Stukienè (Vilnius, 2015), pp. 221-247.

DRUNGILAS, Jonas. Lenku bajorų integracija Žemaitijoje: migracija, kalba, atmintis XVI-XVIII a. PhD dissertation (Vilnius, 2018).

DWORZACZEK, Włodzimierz. Genealogia (Warszawa, 1959).

GUDMANTAS, Kęstutis. Žemaičių bajoro įrašai Viso pasaulio kronikoje, in: Lietuvos Didžiosios Kunigaikštystès kalbos, kultūros ir raštijos tradicijos, ed. S. Temčinas [et. al.] (Vilnius, 2009), pp. 28-44.

HALLOWELL, Robert E. 'Ronsard and the Gallic Hercules Myth', in: Studies in the Renaissance, Vol. 9 (1962), pp. 242-255.

KAŁAMAJSKA-SAEED, Maria 'Genealogia portretowa Sapiehów i jej twórcy', in: Sapiehowie epoki Kodnia i Krasiczyna (Lublin, 2007).

Lietuvos metraštis: Bychovco kronika, translation and introduction by R. Jasas (Vilnius, 1971). 
LIŠKEVIČIENĖ, Jolita. Mundus emblematum: XVII a. Vilniaus spaudiniu iliustracijos (Vilnius, 2005).

LIŠKEVIČIENĖ, Jolita. XVI-XVIII amžiaus knygu grafika: herbai senuosiuose Lietuvos spaudiniuose (Vilnius, 1998).

MAČIULIS, Dangiras, PETRAUSKAS, Rimvydas, STALIŪNAS, Darius. Kas laimèjo Žalgirio mūšį? Istorinio paveldo dalybos Vidurio ir Rytu Europoje (Vilnius, 2012).

MASLAUSKAITĖ, Sigita. 'Šv. Kazimieras karys', in: Kaip tai atsitiko didžiajame mūšyje ... Žalgirio atodangos: taptautinès parodos katalogas (Vilnius, 2010).

NIESIECKI, Kasper. Herbarz Polski, t. IX (w Lipsku, 1842).

PAUL, Nicholas L. To Follow in their Footsteps. The Crusades and Family Memory in the High Middle Ages (New York, 2012).

PETRAUSKAS, Rimvydas. 'Atrandant protèvius: genealoginio mąstymo prielaidos ir užuomazgos Lietuvoje XIV-XVI a. viduryje', in: Ministri historiae. Pagalbiniai istorijos mokslai Lietuvos Didžiosios Kunigaikštystès istorijos tyrimuose. Moksliniu straipsniu rinkinys, skirtas dr. Edmundo Rimšos 65-mečio sukakčiai, eds. Z. Kiaupa, J. Sarcevičienė (Vilnius, 2013), pp. 45-63.

RAILAITE், Agnè. 'Jonas Skarulskis ir jo ryšiai su Kantakuzenais: Kauno maršalaičio vestuvių epitalamijo tyrimas', in: Istorijos šaltinių tyrimai, Vol. 3 (Vilnius, 2011), pp. 153-166.

RAILAITĖ, Agnè. 'Šveikauskų genealoginè savimonè', in: Istorijos šaltiniu tyrimai, Vol. 4 (Vilnius, 2012), pp. 187-204.

RAILAITĖ-BARDE், Agnè. 'Klèjos, Mnemosinès ir Atènès dirbtuvių baruose: Ką atskleidžia Lietuvos Didžiosios Kunigaikštystės kilmingujų genealoginiai medžiai ir schemos?', in: Dailès kūrinys - istorijos šaltinis ed. S. Smilingytė-Žeimienè (Vilnius, 2016), pp. 77-101.

RAILAITĖ-BARDE், Agnè. 'Lietuvos Didžiosios Kunigaikštystès kilmingujų genealoginès savimonès XVI-XVIII a. legendinis ir sakralinis aspektai', in: Ministri historiae. Pagalbiniai istorijos mokslai LDK tyrimuose. Moksliniu straipsniu rinkinys, skirtas dr. Edmundo Rimšos 65-mečio sukakčiai, eds. Z. Kiaupa, J. Sarcevičienè (Vilnius, 2013), pp. 45-63.

RAILAITÉ-BARDE், Agnè. 'Oginskių genealoginès savimonès atspindžiai XVII-XVIII a. proginiuose leidiniuose’, in: Kunigaikščiai Oginskiai Lietuvos istorijoje. Kultūrinès veiklos pédsakais - 2, ed. R. ŠmigelskytèStukienè (Vilnius, 2015), pp. 35-56.

RAILAITĖ-BARDE், Agnè. Lietuvos Didžiosios Kunigaikštystès kilminguju genealogine savimone ir jos atspindžiai heraldikoje XVI-XVIII a. PhD dissertation (Vilnius, 2013).

ROUX, Jean Paul. Karalius. Mitai ir simboliai (Vilnius, 2007).

Полное собрание Русских летописей. Летописи Белорусско - Литовские. Летопись Рачинского, eds. Н.Н. Улащик (Москва, 1980), Vol. 35.

РАЙЛАЙЦЕ-БАРДЗЕ, Агне. 'Генеалагічная свядомасць Сапегаў і яе адлюстраванне ў геральдыцы’, in: Arche 3(148) (Минск, 2016), pp. 324-350. 


\title{
TRIUMFUOJANTI LIETUVOS DIDŽIOSIOS KUNIGAIKŠTYSTĖS KILMINGŲJŲ GENEALOGINE SAVIMONE XVII-XVIII A.
}

Santrauka

\author{
$A G N \dot{E}$ RAILAITE-BARDE்
}

Šiame straipsnyje, remiantis XVII-XVIII a. proginiais leidiniais, genealoginiais medžiais ir schemomis, bus bandoma atskleisti, kaip protėvių, pasižymejjusių karyboje, manifestavimas pasireiškè LDK kilmingujų genealoginèje savimonèje. Tyrime bandoma apsvarstyti, kokią vietą LDK kilmingujų genealoginėje atmintyje užèmè įvairių mūšių išaukštinimas turint omenyje vienų garsiausių LDK kautynių kontekstą. Minimuose genealoginiuose šaltiniuose ieškoma, kokių kautynių ir jose dalyvavusių karžygių atmintis yra svarbi LDK kilmingųjų genealoginei savimonei ir kodèl ši atmintis yra selektyvi, t. y. vieni mūšiai ir juose pasižymėję didvyriai yra prisimenami ir išaukštinami, o kiti - pamirštami. Kokių giminių genealoginei reprezentacijai buvo aktuali vieno ar kito mūšio atmintis, kaip ji reiškèsi ir kokiu laikotarpiu prisimenami šiame mūšyje dalyvavę protèviai? Pirmoje šio tyrimo dalyje pristatoma apskritai protevio, kaip kario, atmintis ir kokiais būdais ji pasireiškia. Antroje dalyje dèmesys sutelktas ị konkrečiuose mūšiuose pasižymèjusius protėvius, kokiose kautynèse dalyvavę giminès atstovai prisimenami, garbinami tokiu būdu išskiriant juos iš kitų tarpo.

LDK kilmingụjų militarinė genealoginè savimonė XVII-XVIII a. genealoginiuose medžiuose, schemose ir proginiuose leidiniuose atsispindi per naratyvines ir ikonografines formas. Pastarosios naudojamos ypač retai, tačiau savo siunčiama informacija, kad ir užkoduota simboliuose, svarbumu ir reikšme nenusileidžia naratyve slypiančiam Lietuvos kilmingųjų protèvių - garsių karių šlovinimui. Galima daryti prielaidą, kad Oršos pergalè, vadinama antruoju Žalgiriu, nors ir buvo prisimenama LDK kilmingujų, tačiau nublanko Kircholmo ir Chotino mūšiu šešèlyje, o Jonas Karolis Chodkevičius, kaip šių mūšių didvyris, buvo labiau pageidaujamas ịvairių LDK kilmingụjų giminių protėvių gretose, nei Konstantinas Ostrogiškis. Tai galèjo sąlygoti ne vienas faktorius. Oršos mūšis laiko požiūriu buvo kur kas labiau nutolęs, nei Kircholmo ir Chotino kautynès. Be to, XVII-XVIII a. jau galime kalbèti apie susiformavusią LDK kilmingųų genealoginę savimonę, kuri glaudžiai siejosi su istorine savimone. XVI a. jos buvo tik užuomazgos. XVII-XVIII a. daug gausiau sužydèjo rašto kultūra. Dèl viso to susikloste palankesnès aplinkybès įvykius ir asmenis prisiminti, jei būtina - pakoreguoti kilmès pasakojimus reikiama linkme ir šias žinias perduoti ateinančioms kartoms. Militarinis genealoginès savimonės aspektas būdingas tiek diduomenei, tiek žemesnio rango LDK kilmingujų atstovams, galèjusiems pasigirti stipria genealogine savimone. LDK kilmingųjų genealoginę savimonę XVIII a., o ypač XVII a., iš tikrujų galime pavadinti triumfuojančia, nes militarinis genealoginès savimonès aspektas buvo vienas iš keturių populiariausių tarp kilmingujų, tačiau pagrindinès LDK kilmingujų genealoginès savimonės triumfo arką puošiančios pergalès buvo Kircholmas ir Chotinas, o ne Žalgiris ar Orša. 